\title{
PENILAIAN KINERJA PENGELOLAAN DAERAH ALIRAN SUNGAI BERBASIS MODEL HIDROLOGI ELEMENTER KASUS: DAERAH TANGKAPAN AIR WADUK MRICA
}

\author{
Performance Assessment of Watershed Management Based on Elementary Hydrological Models \\ Case: The Catchments Area of Mrica Reservoir \\ Lukman Hidayat', Sahid Susanto², Putu Sudira², Rachmad Jayadi ${ }^{3}$ \\ ${ }^{1}$ Jurusan Teknologi Pertanian, Fakultas Pertanian, Universitas Bengkulu \\ Jl. W.R. Supratman Kandang Limun Bengkulu 38371 \\ ${ }^{2} J u r u s a n$ Teknik Pertanian, Fakultas Teknologi Pertanian, Universitas Gadjah Mada \\ Jl. Flora No. 1, Bulaksumur, Yogyakarta 55281 \\ ${ }^{3}$ Program Pascasarjana, Fakultas Teknik Universitas Gadjah Mada \\ Jl. Grafika No. 2, Kampus UGM, Yogyakarta 55281 \\ Email: lukman_hidayat@mail.ugm.ac.id
}

\begin{abstract}
ABSTRAK
Alih fungsi lahan dari hutan menjadi lahan budidaya tanaman sayuran yang belum sepenuhnya mengikuti kaidah konservasi semakin menambah laju sedimentasi yang masuk ke waduk Mrica. Waduk yang mulai beroperasi tahun 1989, akan dipenuhi sedimenpada tahun 2021. Kompleksitas pengelolaan kawasan DAS masih membutuhkan suatu inovasi pendekatan hidrologi untuk memperbaiki situasi,terutama untuk melestarikan sumberdaya air. Fenomena perubahan dan alih fungsi lahan dan dampak kinerja yang ditimbulkan, merupakan kejadian di alam yang perlu dipahami untuk menentukan tindakan yang perlu dilakukan di waktu yang akan datang. Model hidrologi dipandang sebagai alat ekstrapolasi yang dapat membantu memahami fenomena tersebut. Penelitian ini bertujuan untuk mengoptimalkan pengelolaan DAS, menggunakan pendekatan kuantitatif berbasis model hidrologi elementer. Tulisan ini, menggunakan metode kajian pustaka,difokuskan untuk mengungkapkan konsepsi penelitian,sebagai metode pendekatan dalam mencapai tujuan. Konsepsi penelitian yang dimaksud yaitu perakitan-rangkaian serial model hidrologi dan penilaian kuantitatif pengelolaan DAS terkait kinerjanya. Dalam konsep perakitan tersebut akan diaplikasikan model hidrologi sebagai basis penilaian kuantitatif kinerja DAS. Hasil perakitan akan memberikan gambaran peran model hidrologi dalam menghasilkan informasi yang berkaitan dengan kinerja pengelolaan DAS berbasis output. Informasi tersebut dapat digunakan sebagai alternatif masukan dalam kebijakan pengelolaan DAS-Sumberdaya air dan menjadi dasar pengembangan model hidrologi spesifik daerah tangkapan air waduk Mrica.
\end{abstract}

Kata kunci: Model hidrologi, penilaian kuantitatif, kinerja pengelolaan DAS

\begin{abstract}
Land conversionfromforest tocultivation ofvegetablecropsthat did notfollow the rules ofconservation practices, increased therate ofsedimententeringthe reservoirof Mrica. The reservoir which have been operated since 1989, will be full of sediment in 2021. Complexity of managing watershed areas still require an innovative approach to improve the hydrological situation, particularly to conserve water resources. The phenomenon of land use change and performance impacts caused, an event in nature that are necessary to determine the action that needs to be done in the future. Hydrologica lmodels is an extrapolation tool that can help understanding the phenomenon. This study aims at optimizing the performance-related watershed management, using a quantitative approach based on elementery hydrological models. This paper, using the method of literature review, was focused on revealing conception, as the approach in achieving the goal. The conception ofthe study wasthe assembly-serialsequence of hydrological models and watershed management-related quantitative assessment performance. The concept of the assembly will apply the role of hydrological models as a basis for quantitative assessment of performance-related watershed. The results of assembly,
\end{abstract}


will provide an overview of the role of hydrological models, to produce information relating to the performance of output-based watershed management. Information obtained from such a role can be used as an alternative input in policy of water resources management and the basis for the development of specific hydrological models for Mrica reservoirs.

Keywords: Hydrological models, quantitative assessment, watershed management performance,

\section{PENDAHULUAN}

Perkembangan jumlah penduduk membawa akibat terhadap kenaikan kebutuhan air. Sekarang, air yang tersedia sebanyak $750 \mathrm{~m}^{3}$ per kapita per tahun, dan diperkirakan pada tahun 2050 akan menjadi $450 \mathrm{~m}^{3}$ perkapita per tahun, sehingga pada keadaan tersebut $80 \%$ negara di dunia dalam kondisi yang kekurangan air (World Bank, 2010).

Di Indonesia, boleh jadi keadaan tersebut di atas akan menjadi lebih parah kondisinya, mengingat degradasi Daerah Aliran Sungai (DAS), khususnya di Jawa, terus terjadi dan sulit untuk dicegah, walupun. sejak 1970-an pemerintah Indonesia telah mengimplementasikan beberapa program rehabilitasi yang berhubungan dengan pengelolaan DAS/ sumberdaya air, seperti reboisasi-penghijauan, tindakantindakan konservasi tanah, dan lainnya.

Kawasan hulu daerah tangkapan air (DTA) Mrica, dengan luas total mencapai 100.755,81 Ha, yang seharusnya merupakan kawasan konservasi telah mulai dirambah menjadi area aktivitas usaha tani. Kini, indek penutupan lahan (IPL) produksi telah mendekati $80 \%$ dari luas total kawasan DAS, sisanya sekitar $20 \%$ terdiri atas, kawasan hutan, semak belukar, rawa, padang rumput, tubuh air, gedung dan pemukiman. Alih fungsi lahan dari hutan menjadi lahan budidaya tanaman sayuran yang belum sepenuhnya mengikuti kaidah konservasi, semakin menambah laju sedimentasi yang masuk ke waduk Mrica. Sedimentasi di Waduk Mrica, yang membendung sungai Serayu di Banjarnegara, sangat tinggi akibat kerusakan lingkungan di DAS Serayu yang sudah mencapai 80\% (Widiyatno, 2011). Dengan kapasitas waduk 140 juta $\mathrm{m}^{3}$, yang mulai dioperasikan tahun 1989 dan laju sedimentasi 4,20 juta $\mathrm{m}^{3}$ per tahun, maka pada tahun 2021 akan penuh sedimen (Soewarno dan Syariman, 2008 dalam Mulyana dkk., 2011).

Kompleksitas kawasan DAS masih membutuhkan suatu inovasi pendekatanhidrologiuntuk memperbaiki situasi,terutama untukmelestarikan sumberdaya air (Susanto and Kaida, 1991). Dengan melakukan telaah konsep daur hidrologi secara lebih luas, maka pengertian istilah daur, kemudian dapat dijadikan sebagai konsep kerja untuk analisis dari berbagai macam permasalahan, misalnya perencanaan dan evaluasi pengelolaan DAS. Fenomena perubahan dan alih fungsi lahandan dampak yang ditimbulkan merupakan kejadian di alam yang perlu dipahami untuk menentukan tindakan yang perlu dilakukan di waktu yang akan datang. Model hidrologi elementer, yang tersusun atas elemen hidrologi dasar, seperti hujan, penguapan, resapan, simpanan, dan aliran, dipandang sebagai alat ekstrapolasi yang dapat membantu memahami fenomena tersebut.

Pemodelan hidrologi tersebut memunculkan pemikiran bahwa model hidrologi dapat digunakan sebagai basis pengelolaan DAS terkait penilaian kinerjanya. Namun, pertanyaannya "apa dan dan bagaimana peran model hidrologi dalam pengelolaan DAS, khususnya di kawasan hulu waduk Mrica?".

Tujuan penelitian ini yaitu untuk mengoptimalkan pengelolaan DAS terkait kinerja, menggunakan pendekatan penilaian kuantitatif berbasis model hidrologi elementer. Paper ini difokuskan untuk mengungkapkan konsepsi penelitian sebagai pendekatan untuk mencapai tujuan. Konsepsi penelitian yang dimaksud yaitu perakitan-rangkaian serial model hidrologi dan penilaian kuantitatif pengelolaan DAS terkait kinerjanya. Hasil perakitanakan memberi gambaraninformasi peran model hidrologi dalam pengelolaan DAS terkait kinerja. Informasi yang diperoleh, disamping dapat dijadikan pendukung keputusan dalam optimalisasi pengelolaan DAS, juga sangat mungkin menjadi alternatif masukan dalam kebijakan pengelolaan sumberdaya air dan menjadi dasar pengembangan model hidrologi spesifik untuk kawasan DAS yang karakternya menyerupai kawasan atau DTA hulu waduk Mrica.

\section{METODE PENELITIAN}

Kajian pustaka merupakan landasan metode penelitian ini untuk mengungkap konsepsi penelitian.. Oleh karena itu, uraiannya diawali dengan landasan teori dalam menyusun kerangka dasar penelitian sebagai konsep perakitan model hidrologi dengan pengelolaan DAS terkait kinerjanya. Lokasi penelitian yaitu di kawasan DAS daerah tangkapan air (DTA) waduk Mrica seluas 100.755,81 ha.

\section{Landasan Teori}

Ekosistem DAS, terutama di bagian hulu merupakan bagian yang penting, karena mempunyai fungsi perlindungan 


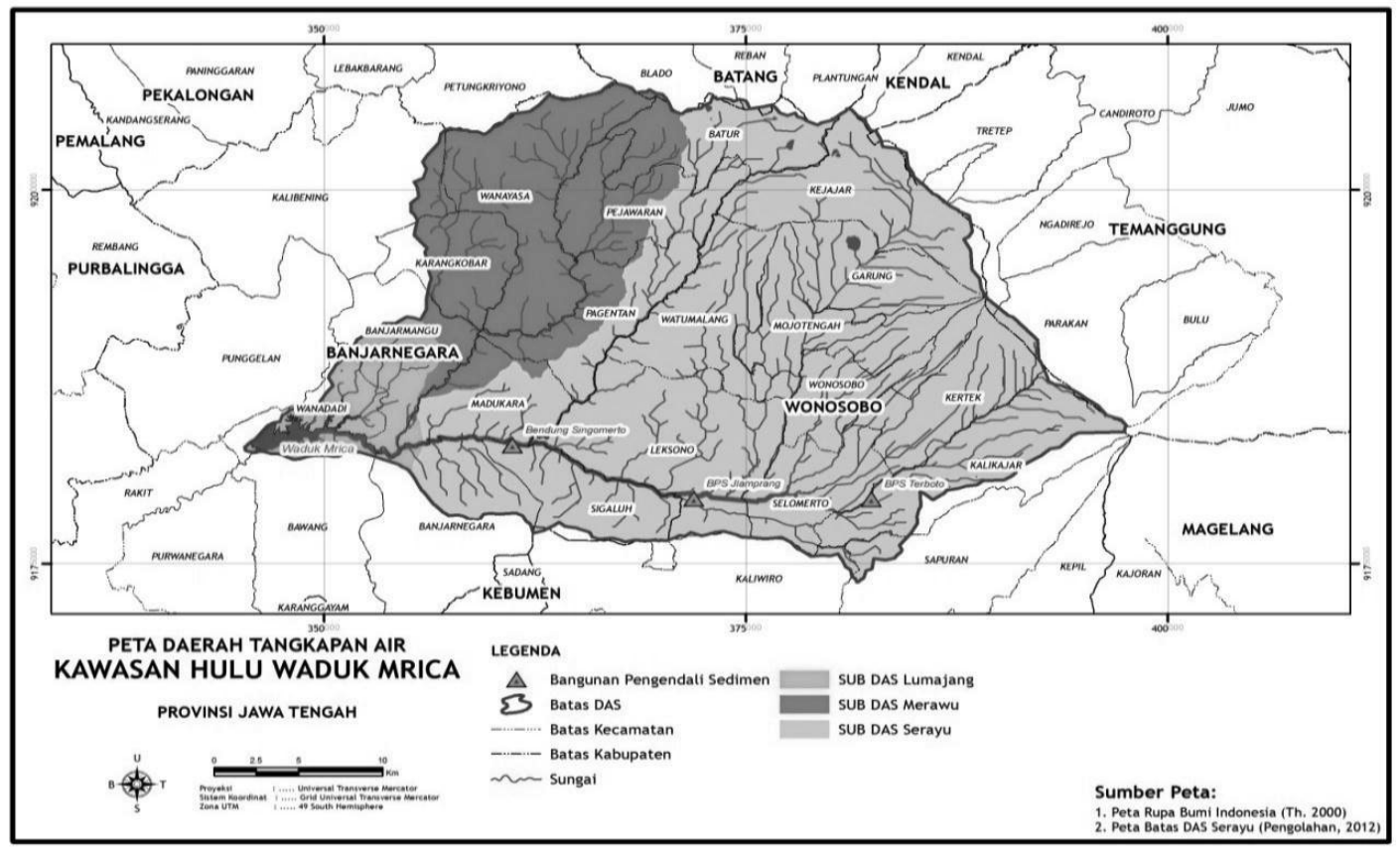

Gambar 1. Daerah Tangkapan Air (DTA) hulu Waduk Mrica

terhadap keseluruhan bagian DAS. Terdapat bentuk keterkaitan daerah hulu dan hilir, praktek-praktek pengelolaan lahan dan atau pembuatan bangunan konservasi di lahan maupun di sungai di bagian hulu, dapat memberi dampak dalam bentuk perubahan fluktuasi debit air, sedimen terangkut dan material terlarut lainnya pada bagian hilir. Pengelolaan DAS dengan baik dan optimal memerlukan pendekatan yang menyeluruh terhadap semua aspek dan komponen yang mempengaruhinya. Pengelolaan tata guna lahan DAS, terutama di lahan bagian atas dan tengah, penting karena dari areal bagian ini aliran air permukaan dapat mengalir dengan deras dan tanah lebih mudah terkikis (Asdak, 2010; Permenhut No. 32/Menhut-II/2009).

DAS sebagai suatu obyek yang mempunyai karakter resiko dan kerentanan tertentu dalam merespon setiap perubahan yang terjadi dalam sistem hidrologi, dapat menggunakan pendekatan penilaian kuantitatif, untuk pengelolaannya (Aller dkk., 1987; Hathhorn dan Hubbena, 1996; Pastakia, 1998; Eimers dkk., 2000. dalam Diamantino dkk., 2007; Paulo S.F. De Araujo dan Naim Haie, 2007). Penilaian kuantitatif dapat dilakukan dengan cara memberi nilai tertentu "skoring" pada setiap indikator terkait kinerja dalam kerangka pengelolaan DAS. Indikatornya meliputi indikator dasar dan indikator antara atau tambahan. Indikator dasar merupakan indikator output, yang dapat memberikan informasi terkait kondisi hidrologi DAS. Indikator antara merupakan indikator input dan dampak, yang menyampaikan informasi-informasi terkait kelembagaan dan sosial-ekonomi atau peran serta dan pemahaman masyarakat dalam Pengelolaan DAS. Bobot dan skor pada masing-masing indikator ditetapkan menggunakan "meta model"- pendapat para ahli hidrologi yang telah diaplikasikan dan buku panduan dari
Balitbang Teknologi Pengelolaan DAS Wilayah Indonesia Bagian Barat, Departemen Kehutanan RI (2003), serta Panduan Monev Prasarana Sumberdaya Air, Kementerian Pekerjaan Umum (2010) .

Oleh karena itu, sangat mungkin jika indexing digunakan juga untuk menilai kondisi hidrologis suatu kawasan DAS. Kondisi hidrogis yang dihasilkan akan mencerminkan kinerjanya dan kinerja tersebut dapat dijadikan pendukung keputusan dalam pengelolaan DAS.

Melalui pendekatan penilaian kuantitatif berbasis output, model hidrologi yang mampu menggambarkan respon kawasan DAS, pada kondisi yang ada maupun mendatang, mempunyai peran mendasar dalam penilaian terkait kinerja dalam kerangka pengelolaan DAS. Respon perubahan kawasan DAS diharapkan terjadi-terlihat karena model hidrologi mampu melakukan simulasi berdasarkan skenario-skenario yang diinginkan-ditetapkan.

Model hidrologi spasial dan terdistribusi Soil Water Assessment Tool (SWAT) yang telah diaplikasikan dengan memuaskan di banyak tempat dan karakter di dunia, dapat digunakan sebagaidasarpengelolaankawasanDAS(Suryani, E. dan Agus, F., 2005; Omani dkk., 2007; Ndomba, P.M dan B.Z. Biharman, 2008; AAAE, 2009; Douglas-Mankin dkk., 2010; Mechram, S., 2010, Bakhtiar dkk., 2010; Xie dan Cui, 2011). Dalam operasionalnya, Model SWAT dapat melakukan beberapa simulasi, di antaranya praktek-praktek pengelolaan di lahan dan di saluran-sungai, di antaranya perubahan tataguna lahan, praktek konservasi tanah dan air, dan keberadaan pound - bangunan pengendali sedimen terangkut (Neitsch dkk., 2005; Williams dkk., 2008,, Arnold 
dan Allen, 1996 dalam Rossi dkk., 2009; Arnold dkk., 2010; Gassman dkk., 2007dalam Douglas-Mankin dkk., 2010). Luaran utama, kondisi hidrologi, yang dihasilkan berupa nilai debit, erosi, dan sedimen terangkut. Nilai-nilai tersebut dapat memungkintan nilai-nilai kondisi hidrologi terkait kinerja DAS seperti, koefisien regim sungai (KRS), sediment delivery ratio (SDR), nilai coefficient runoff $\mathrm{C}$ dapat juga dihitung.

\section{Kerangka Dasar Penelitian}

Tabel 1. Kerangka dasar penelitian sebagai konsep perakitan
Kerangka dasar penelitian sebagai konsep perakitanrangkaian serial model hirologi elementer dan pengelolaan DAS terkait kinerjanya disusun dalam matrik sepert ditunjukkan pada Tabel 1.

Konsep tersaji dalam Tabel 1 menjelaskan bahwa model simulasi hidrologi dapat memprediksi dan meramalkan kondisi hidrologi, sebagai indikator dasar dalam pengelolaan DAS. Simulasi skenario-skenario yang ditetapkan, diharapkan mampu memperlihatkan signifikansi perubahan respon

Model hidrologi elementer

Pengelolaan DAS

(penilaian kuantitatif terkait kinerja DAS)

\begin{tabular}{lll} 
& Indikator kinerja (Nilai = bobot x skor) & \multicolumn{1}{c}{ Keterangan } \\
\cline { 2 - 3 } & & $\begin{array}{l}\text { (Kondisi hidrologi-respon kawasan DAS): } \\
\text { dihasilkan-diperoleh dari pemodelan hidrologi } \\
\text { menggunakan pendekatan simulasi beberapa } \\
\text { skenario. }\end{array}$ \\
\cline { 2 - 3 } $\begin{array}{l}\text { Kondisi hidrologi } \\
\text { (Erosi, Debit, Sedimen, KRS, dll) dioptimasi } \\
\text { dengan cara simulasi beberapa skenario } \\
\text { manipulasi penutup tanah "land cover" di }\end{array}$ & $\begin{array}{c}\text { Indikator antara/tambahan (Indikator } \\
\text { input dan dampak) }\end{array}$ & $\begin{array}{l}\text { Komponen teknologi dan dampak pengelolaan } \\
\text { (melibatkan lembaga-organisasi dan masyarakat } \\
\text { lahan dan keberadaan bangunan pengendali } \\
\text { sedimen terangkut di sungai }\end{array}$ \\
\hline
\end{tabular}

kawasan DAS terkait penilaian kinerja pengelolaan DAS. Perakitan-rangkaian serial model hidrologi elementer dan pengelolaan DAS terkait kinerja menggunakan penilaian kuantitatif berbasis output. menegaskan peran model hidrologi dalam menghasilkan informasi nilai kuantitatifskoring kinerja, yang dapat dijadikan pendukung keputusan dalam pengelolaan DAS. Model hidrologi dan perannya dalam pengelolaan DAS, akan dijalankan pada keadaan existing atau kondisi sekarang dan pada kondisi optimasi dengan cara simulasi, melalui beberapa skenario tataguna lahan dan bangunan pengendali sedimen. Skenario simulasi dan proporsinya Tabel 2 dan 3, yaitu:

Skenario-skenario yang digunakan tersebut di dasarkan pada peraturan-peraturan dan pedoman-pedoman terkait dengan pengelolaan DAS dan konservasi sumberdaya alam, terutama yang berkaitan dengan manipulasi land cover perubahan tataguna lahan, di antaranya: Permen 32/Menhut-

Tabel 2. Gambaran simulasi penelitian berdasar pada skenario-skenario

Model Hidrologi $\quad \begin{gathered}\text { Pengelolaan DAS(Penilaian } \\ \text { kuantitatif terkait kinerja DAS) }\end{gathered}$

$\begin{array}{cccc}\text { Kalibrasi dan verifikasi } & \text { Skoringpengelolaan DAS } & \text { Kondisi DAS } \\ \text { (Validasi Model) } & \text { (existing) } & \text { sekarang }\end{array}$

\begin{tabular}{|c|c|c|c|c|}
\hline \multirow{3}{*}{$\begin{array}{ll}\text { Simulasi } \\
\text { 1. Tataguna lahan } \\
\text { 2. Pengendali sedimen } \\
\text { terangkut }\end{array}$} & Skenario 1 & Luaran skenario 1 & $\begin{array}{c}\text { Skoring pengelolaan DAS } \\
\text { (skenario 1) }\end{array}$ & \multirow{3}{*}{$\begin{array}{c}\text { Kondisi DAS } \\
\text { optimasi }\end{array}$} \\
\hline & Skenario 2 & Luaran skenario 2 & $\begin{array}{c}\text { Skoring pengelolaan DAS } \\
\text { (skenario 2) }\end{array}$ & \\
\hline & Skenario $n$ & Luaran skenario $n$ & $\begin{array}{c}\text { Skoring pengelolaan DAS } \\
\text { (skenario } n)\end{array}$ & \\
\hline
\end{tabular}


Tabel 3. Proporsi skenario simulasi

\begin{tabular}{|c|c|c|c|c|c|}
\hline & & \multicolumn{2}{|c|}{ Tataguna lahan } & \multirow{2}{*}{$\begin{array}{c}\text { Bangunan Pengendali Sedimen } \\
\text { Terangkut(BPS) } \\
\text { (unit) }\end{array}$} & \\
\hline & & $\begin{array}{c}\text { IPL } \\
\operatorname{Per}(\%)\end{array}$ & $\begin{array}{c}\text { IPL } \\
\text { Prod }(\%)\end{array}$ & & \\
\hline \multicolumn{2}{|c|}{ Existing } & 11.41 & 79.96 & 3 & Kondisi sekarang \\
\hline \multirow{3}{*}{$\begin{array}{l}\text { Simulasi } \\
\text { (skenario) }\end{array}$} & $E X^{-*}$ & 2 & 88 & 10 & \multirow{3}{*}{ Kondisi optimasi } \\
\hline & $R a$ & \multicolumn{2}{|c|}{$20 \leq R a \leq 70$} & $30 \leq B P S \geq 10$ & \\
\hline & $E X+*$ & 88 & 2 & 30 & \\
\hline
\end{tabular}

II/2009, SK Menhut 52/Kpts/2001; Dirjen Sumberdaya AirKementerian PU, Balitbang Teknologi Pengelolaan DAS Wilayah Indonesia Bagian dan Badan Litbang KehutananPuslitbang Hutan dan Konservasi Alam.

\section{a. Existing-Kondisi Sekarang}

Manipulasi Land cover - tataguna lahan. Indeks penutupan lahan produksi IPLProd yang meliputi: kebun, sawah tadah hujan dan irigasi, serta tegalan luasnya 79,96\% luas DAS; sementara Indeks penutupan lahan permanen IPLPer yang meliputi semak/belukar, hutan, rawa dan padang rumput luasnya mencapai $11,41 \%$ luas DAS. Sisanya, seluas $8,63 \%$ yang terdiri dari air tawar/muka air waduk, pemukiman dan gedung tidak diperhitungkan dalam kegiatan simulasi manipulasi land cover.

Bangunan Pengendali Sedimen (BPS). keberadaannya berjumlah 3 unit.

\section{b. Simulasi (Skenario)-Kondisi Optimasi}

Pada kegiatan simulasi, skenarionyadikelompokkan ke dalam tiga hal, yaitu Ekstrim negatif (EX-); Reasonable alternatives - Rasional (Ra) dan Ekstrim positif (EX+).

Manipulasi Land cover - tataguna lahan. Skenario proporsi IPLProd dan IPLPer, dibuat dengan memperhatikan luasan penggunaan lahan yang ada dan yang memungkinkan akan adanya perubahan (bertambah dan atau berkurang). Skenario Ex-, skenario keadaan yang tidak ada upaya konservasi., alih fungsi lahan dari lahan permanen ke lahan produktif akan terus terjadi. Skenario Rasional ( $R a)$, dibuat, di antaranya mempertimbangkan persentase kelerengan kawasan DAS yang dapat difungsikan-dialihkan sebagai lahan produktif $(<15 \%)$ dan yang lahan yang seharusnya dikonservasi $(\geq 15 \%)$. Skenario $(E x+)$, kebalikan dari $E x$-, suatu skenario keadaan dengan upaya konservasi ideal. Pola tataguna lahan dijalankan sesuai dengan kaidah-kaidah konservasi sumberdaya alam. Lahan konservasi, tidak dirambah menjadi lahan produksi.

Bangunan Pengendali Sedimen (BPS). Skenario bangunan pengendali sedimen terangkut, dibedakan berdasarkan pada jumlah unitnya. Skenario-skenario tersebut yaitu: Ekstrim negatif 10 unit, "Reasonable alternatives" Rasional $(30 \leq B P S \geq 10)$ dan Ekstrim positif 30 unit. BPS akan dibangun di sungai ordo 2, kapasitas sedimen yang harus ditahan diasumsikan sebanyak $40 \%$ dari potensi sedimen yang mengalir di sungai.

\section{HASIL DAN PEMBAHASAN}

Konsep perakitan rangkaian serial model hidrologi elementer dan pengelolaan DAS dikembangkan sebagai kerangka pengelolaan DAS berbasis output, menggunakan pendekatan penilaiankuantitatif-skoring, yang meliputikriteria dan indikator kinerja DAS. Indikator tersebut memberikan informasi terkait kondisi hidrologi DAS, kelembagaan, sosialekonomi atau peran serta dan pemahaman masyarakat dalam pengelolaan DAS. Informasi yang dihasilkan mengikuti alur pikir analisis data sebagai berikut (Gambar 2)

Gambar 2. Alur pikir analisis data

Catatan: Output (kondisi hidrologi: Debit, Erosi, Sedimen dll); Pengelolaan (Penilaian kuantitatif terkait kinerja DAS dalam kerangka Pengelolaan DAS)
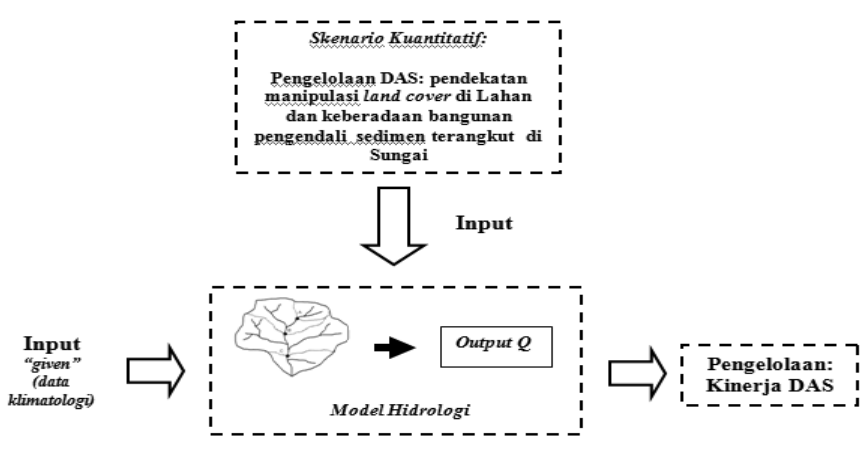

Input data klimatologi "given" dan input skenario kuantitatif tersebut akan diproses model hidrologi menghasilkan output luaran, misalnya debit aliran $(Q)$, erosi, dan sedimen. Kemudian hasilnya diinterpretasi melalui proses validasi (kalibrasi dan verifikasi) berdasarkan kriteria statistik 
dan grafis. Jika hasil interpretasi telah memenuhi kriteria tersebut, kemudian dilanjutkan dengan simulasi skenario untuk pengelolaan atau penilaian berbasis output terkait kinerja DAS melalui pendekatan kuantitatif, dengan cara memberi nilai atau skor terhadap luaran yang dihasilkan model hidrologi.

Berdasarkan pada alur pikir analisis tersebut, maka dapat disusun tahapan penerapankonsep mulai dari penyiapan data dan penyusunan hydrologic respon units (HRUs). HRU, dalam model SWAT, sebagai respon sistem DAS terhadap masukan hujan menjadi luaran berupa aliran- debit, dibuat dengan cara tumpangsusun-overlay peta tataguna lahan, jenis dan kelerengan tanah. Selanjutnya, menjalankan model hidrologi SWAT, melakukan simulasiskenario dan optimasi pengelolaan DAS, mengikuti tahapan penerapan konsep (Gambar 3.). Penilaian kuantitatif terkait kinerja mengikuti tahapan pembobotan, skoring dan penilaian pengelolaan DAS (Gambar 4.). Sementara itu, indikator dan parameter terkait kinerja dalam pengelolaan DAS, disajikan pada Tabel 4.

Gambar 3. Diagram alir tahapan penerapan konsep perakitan

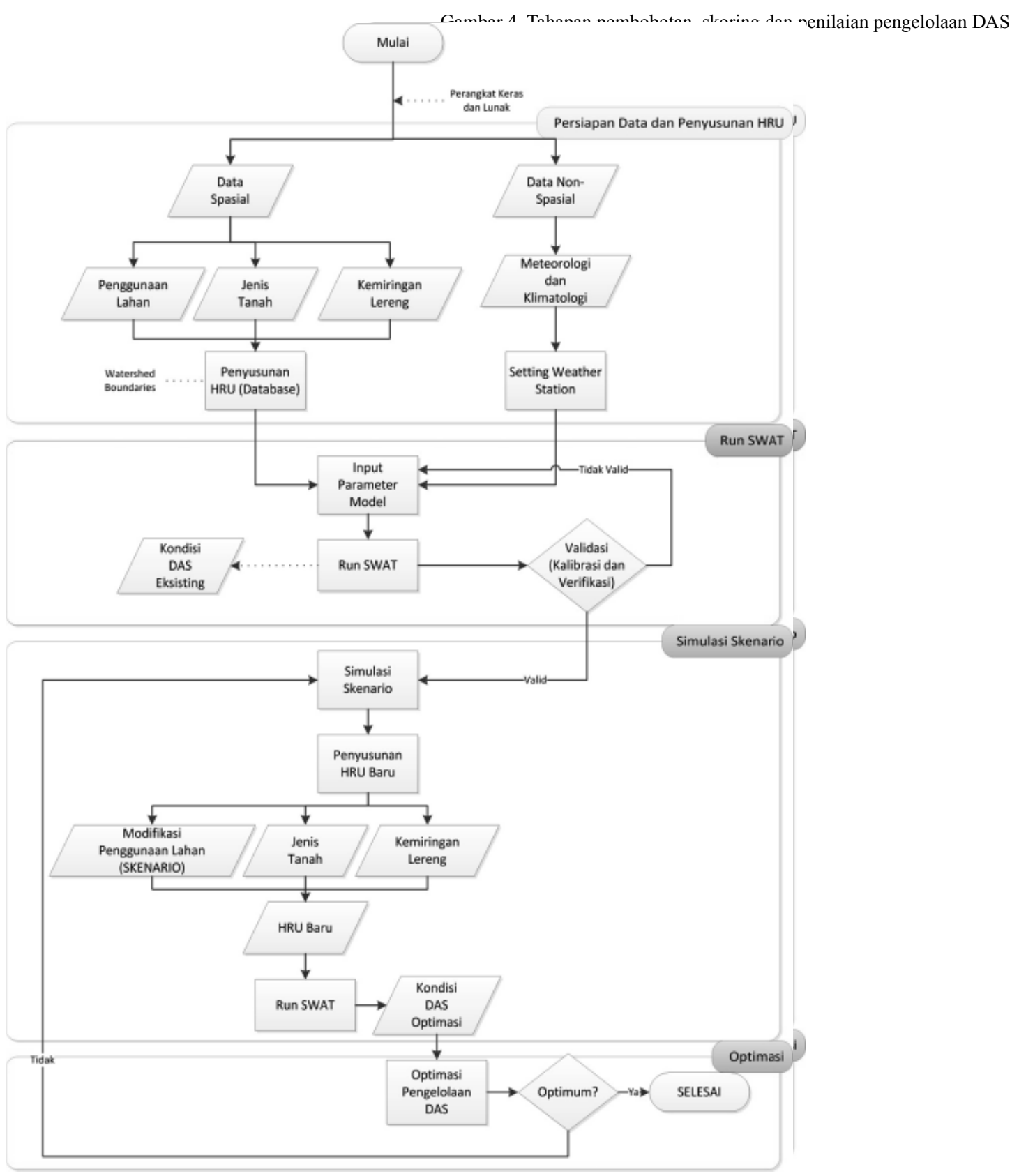

Tabel 4. Indikator dan parameter terkait kinerja dalam pengelolaan DAS 


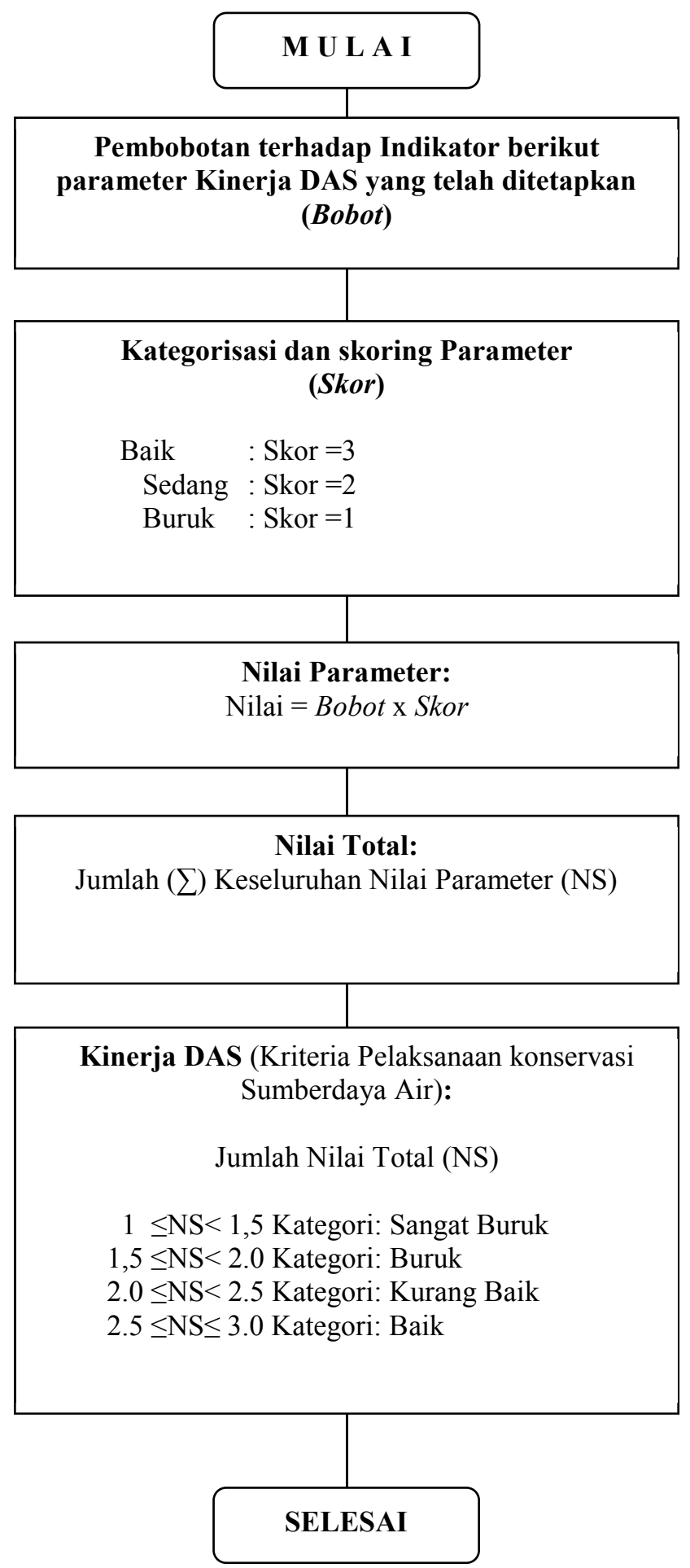




\begin{tabular}{|c|c|c|c|c|c|c|c|}
\hline \multirow{2}{*}{ No } & \multirow{2}{*}{ Parameter } & \multirow{2}{*}{ Satuan } & \multirow{2}{*}{$\begin{array}{c}\text { Bobot } \\
(\%)\end{array}$} & \multirow{2}{*}{$\begin{array}{c}\text { Nilai } \\
\text { Rerata *) }\end{array}$} & \multirow{2}{*}{$\begin{array}{c}\text { Kategori } \\
\text { Nilai }\end{array}$} & \multirow{2}{*}{ Skor } & \multirow{2}{*}{ Nilai } \\
\hline & & & & & & & \\
\hline I & INDIKATOR OUT PUT (40\%) & & & & & & \\
\hline 1 & Kehilangan Tanah/Erosi & ton/ha/ thn & 6 & & & & \\
\hline 2 & Sedimentasi Sungai & $\mathrm{mm} / \mathrm{thn}$ & 5 & & & & \\
\hline 3 & Sedimentasi Waduk & $\mathrm{mm} / \mathrm{thn}$ & 5 & & & & \\
\hline 4 & Debit Maksimum & $\mathrm{m}^{3} / \mathrm{det} / \mathrm{km}^{2}$ & 5 & & & & \\
\hline 5 & Debit Minimum & $\mathrm{m}^{3} / \mathrm{det} / \mathrm{km}^{2}$ & 5 & & & & \\
\hline 6 & Koefisien Regim Sungai (KRS) & - & 6 & & & & \\
\hline 7 & $\begin{array}{l}\text { Ketersediaan Air Waduk } \\
=\text { Rasio vol. aktual/vol.rancangan }\end{array}$ & Juta $\mathrm{m}^{3} / \mathrm{thn}$ & 4 & & & & \\
\hline 8 & $\begin{array}{l}\text { Keseimbangan Air Waduk/Neraca Air } \\
\text { (ketersediaan air thd kebutuhan) }\end{array}$ & Juta $\mathrm{m}^{3} / \mathrm{thn}$ & 4 & & & & \\
\hline II & INDIKATOR INPUT (40\%) & & & & & & \\
\hline 9 & $\begin{array}{l}\text { Bangunan Pengendali Sedimen } \\
\text { (BPS, Check Dam) di Sungai }\end{array}$ & - & 4 & & & & \\
\hline 10 & Gully Plug di Anak Sungai & - & 4 & & & & \\
\hline 11 & $\begin{array}{l}\text { Lahan: Bangunan Terasering/Pengendali Jurang, } \\
\text { Saluran Drainase }\end{array}$ & - & 4 & & & & \\
\hline 12 & Penanaman Pohon di Area Bantaran Sungai & $\%$ & 4 & & & & \\
\hline 13 & Indeks Penutupan Lahan Permanen & $\%$ & 4 & & & & \\
\hline 14 & Indeks Penutupan Lahan Produksi & $\%$ & 4 & & & & \\
\hline 15 & Sistem Manajemen d Base (Data Base) & $\%$ & 2 & & & & \\
\hline 16 & Sistem Manajemen MonevDAS & $\%$ & 2 & & & & \\
\hline 17 & Sistem Manajemen Sumberdaya Manusia (SDM) & $\%$ & 2 & & & & \\
\hline 18 & Sistem Satuan MonevDAS Internal (SMI) & $\%$ & 2 & & & & \\
\hline 19 & Sistem Pelaporan MonevDAS & $\%$ & 2 & & & & \\
\hline 20 & $\begin{array}{l}\text { Investasi peningkatan kapasitas kemampuan } \\
\text { keterampilan dlm menjalankan konservasi sda }\end{array}$ & $\%$ & 3 & & & & \\
\hline 21 & Investasi ekonomi & $\%$ & 3 & & & & \\
\hline III & INDIKATOR TAMBAHAN (20\%) & & & & & & \\
\hline 22 & Produktivitas Lahan & - & 5 & & & & \\
\hline 23 & Ketebalan Solum Tanah & $\mathrm{Cm}$ & 5 & & & & \\
\hline 24 & $\begin{array}{l}\text { Ketergantungan matapencaharian } \\
\text { masyarakat pada lahan }\end{array}$ & $\%$ & 2.5 & & & & \\
\hline 25 & Kepadatan penduduk & Jiwa/ km² & 2.5 & & & & \\
\hline 26 & Pendapatan masyarakat & $\mathrm{Rp} / \mathrm{bln}$ & 2.5 & & & & \\
\hline 27 & Kelembagaan masyarakat & - & 2.5 & & & & \\
\hline & Jumlah & & 100 & & & & \\
\hline
\end{tabular}

*) Nilai Rata-rata:

a) Nilai parameter no 1-8, diturunkan dari nilai luaran pemodelan DAS

b) Nilai parameter no. 9-27, diperoleh dari hasil survey metode PRA dan RRA

Gambaran hasil konsep perakitan yang diawali dari alur pikir analisis data, tahapan penerapan konsep sampai dengan tahapan penilaian kuantitatif-skoring kinerja DAS (Gambar 2, 3, 4, dan Tabel 4), memberikan makna peran mendasar model hidrologi dalam pengelolaan DAS terkait kinerja. Melalui kemampuan dalam melakukan simulasi berdasarkan skenario yang ditetapkan, model hidrologi dapat menduga dan meramalkan respon kawasan DAS yang mencerminkan kinerjanya. Respon 
tersebut berupa nilai-nilai kondisi hidrologi seperti, debit aliran, sedimen terangkut, erosi, dan nilai-nilai KRS, SDR dan C. Nilai-nilai tersebut dapat digunakan sebagai indikator dasar (output) Kinerja DAS. Hasil penilaian kuantitatifskoring terhadap indikator dasar dan tambahan (diperoleh dengan cara survey) dapat dijadikan pendukung keputusan pengelolaan DAS, yang meliputi perencanaan, pelaksanaan dan pengorganisasian.

\section{KESIMPULAN}

Perakitan-rangkaian serial Model hidrologi elementer dengan pengelolaan DAS terkait kinerja melalui pendekatan penilaian kuantitatif, menginformasikan peran modelhidrologi sebagai basis dalam pengelolaan DAS. informasi peran tersebut mempunyai kontribusi bermakna terhadap:

1. Pengembangan ilmu, model hidrologi spesifik untuk kawasan DAS yang karakter- nya menyerupai kawasan hulu daerah tangkapan air waduk Mrica

2. Kegiatan terapan (praktis), sebagai alternatifmasukan dalam kebijakan pengelolaan sumberdaya air .

\section{DAFTAR PUSTAKA}

AAAE.(2009) Special issue SWAT Southeast Asia modelling. International Agricultural Engineering Journal, AAAE, 2009 18(1-2): 15-25.

Asdak, C.(2010). Hidrologi dan Pengelolaan Daerah Aliran Sungai. Gadjah Mada University Press, Yogyakarta.

Arnold, J.G., Allen, P.M., Volk, M., Williams, J.R. dan Bosch, D.D. (2010). Assessment of different representaations of spatial variability on SWAT model performance. The ASABE SWAT 2010 special collection. Transaction of The ASABE 53(5): 1433-1443.

Badan Penelitian dan Pengembangan Kehutanan (2003). Balai Penelitian dan Pengembangan Teknologi Pengelolaan DAS Wilayah Indonesia Bagian Barat. Departemen Kehutanan Republik Indonesia.

Badan Penelitian dan Pengembangan Kehutan (2004). Pusat Penelitian dan Pengembangan Hutan dan Konservasi Alam. Info DAS No. 15/ 2003 ISSN 1410-1114. Departemen Kehutanan Republik Indonesia.

Bakhtiar, Hadihardaja, J. dan Hadiardaja, I.K. (2010). Determining the critical degree of reservoir lifetime for the saguling reservoir based on the sediment inflow simulation. Jurnal Teknik Sipil 17(1): 47-62.

Departemen Kehutanan RI. (2001). Keputusan Menteri KehutananNo.52/Kpts-II/2001 tentangPenyelenggaraan
Pengelolaan DAS. Departemen Kehutanan Republik Indonesia.

Diamantino, C., Maria, J.H., Manuel, M.O. dan Joao-Paulo, L.F. (2007). Methodologies for pollution risk assessment of water resources system. proceeding of the fourth interceltic colloquium on hydrology and management water resources; Guimaraes, Portugal, July 2005. The International Association of Hydrological Science Pubication 310 (2007): 298-306.

Douglas-Mankin, K.R., Srinivasan, R.dan Arnold, J.G. (2010). Soil and water assessment tool (SWAT) model: current developments and applications. The ASABE SWAT 2010 Special Collection. Transaction of The ASABE 53(5): 1423-1431.

Kementerian Kehutanan RI. (2009). Peraturan Menteri Kehutanan No. P.32/Menhut-II/2009 tentang Cara Penyusunan Rencana Teknik Rehabilitasi Hutan dan Lahan Daerah Aliran Sungai (RTRHL-DAS). Kementerian Kehutanan Republik Indonesia.

Kementerian Pekerjaan Umum(2010). Panduan Monitoring dan Evaluasi Prasarana Sumberdaya Air. Kementerian Pekerjaan Umum-Dirjen Sumberdaya Air, Satuan Kerja Balai Besar Wilayah Sungai Serayu Opak.

Mechram, S. (2010). Prediksi Limpasan Permukaan, Erosi dan Sedimentasi Menggunakan Model AVSWAT 2000 (Studi Kasus di Sub DAS Bengawan Solo Hulu). Tesis. Tidak dipublikasikan.Program Pascasarjana. Fakultas Teknologi Pertanian. Universitas Gadjah Mada, Yogyakarta.

Mulyana, A.R., Singgihm H., Soewarno. dan Subagyo, A.(2011). Pengendalian daya rusak air pada hulu DAS rawan aliran lumpur di kawasan dataran tinggi Dieng. Proceeding Kolokium Hasil Litbang Sumberdaya Air. Pusat Penelitian Pengembangan Sumberdaya Air, Badan Penelitian Pengembangan, Kementerian Pekerjaan Umum. Bandung 23-24 Maret 2011.

Ndomba, P.M. dan Birhanu, B.Z. (2008). Problems and prospect of SWAT model aplications in NILOTIC catchments: a rewiew. Nile Basin Water Engineering Scientific Magazine 1: 41-51.

Neitsch, S.L., Arnold, J.G., Kiniry, J.R. dan Williams, J.R. (2005). Soil and Water Assessment Tool Theoritical and Documentation, Version 2005. Grassland, Soil and Water Research Laboratory-Agricultural Research Service 808 East Blackland Road-Temple, Texas 76502. Blackland Research Center-Texas Agricultural Experiment Station 720 East Blackland Road-Temple, Texas 76502.

Omani, N., Tajrishy, M.dan Abrishamchi, A.(2007). Modelling of a river basin using SWAT and GIS. $2^{\text {nd }}$ International 
Conference on Managing Rivers in The $21^{\text {st }}$ Century: Solutions Towards Sustainable Rivers Basins. Riverside Kuching, Sarawak, Malaysia. June 6-8, 2007

Paulo, S.F., De, A. dan Haie, N. (2007). Application of RIAM to the environmental impact assessment of hydroelectric installation. Proceeding of The Fourth InterCeltic Colloquium on Hydrology and Management Water Resources; Guimaraes, Portugal, July 2005. The International Association of Hydrological Science Publication. 310.(2007): 320-326.

Rossi, C.G., Sinivasan, R., Jirayoot, K., Le Due, T., Souvannabouth, P., Binh, N. dan Gassman, P.W. (2009). Hydrologicic evaluation of the lower mekong river basin with the soil and water assessment tool model. International Agricultural Engineering Journal AAAE 18(1-2): 1-13.

Suryani, E. dan Agus, F. (2005). Perubahan penggunaan lahan dan dampaknya terhadap karakteristik hidrologi: suatu studi di DAS Cijalupang, Bandung, Jawa Barat. Prosiding Multifungsi Pertanian:87-104. ISBN: 9799474-42-6.

Susanto, S.dan Kaida Y.(1991). Tropical hidrology simulation model-1 for watershed management (1) model building. Journal of Japan Society Hydrology and Water Resource 4(2): 43-53.

Widiyatno, E. (2011). DAS Serayu kritis.Republika 28 November 2011.

World Bank (2010). Integrated Water Resources Management (IWRM). World Bank Report.

Xie, X. dan Cui, Y. (2011). Development and test of SWAT modelling hydrological process in irrigation with paddy rice. Journal of Hydrology 396: 61-71. 